\title{
SYNTHESIS, CHARACTERIZATION, AND ANTIMICROBIAL EVALUATION OF 3,5-DISUBSTITUTED TRIAZOLES BEARING 5-CHLORO-2-METHYLINDOLE
}

\author{
SABA SHIREEN, BHARATH RATHNA KUMAR P* \\ Department of Pharmaceutical Chemistry, Anwarul Uloom College of Pharmacy, Hyderabad, Telangana, India, \\ Email: bharathpharm@gmail.com.
}

Received: 19 July 2019, Revised and Accepted: 20 August 2019

\section{ABSTRACT}

Objectives: Synthesis, characterization, and antimicrobial evaluation of some novel 1,2,4-triazole derivatives clubbed with indole.

Methods: Procedure includes the synthesis of 1,2,4-triazole compounds by condensation reaction with ammonia. The synthesis was carried out in three steps with chlorophenylhydrazine hydrochloride as starting material with ethyl acetoacetate and hydrazine hydrate in the presence of ethanol to form hydrazide derivative. The hydrazide derivative then refluxed with ammonium acetate to get the desired compounds.

Results: All the synthesized compounds were characterized and confirmed by Fourier-transform infrared spectroscopy, mass spectroscopy, and nuclear magnetic resonance spectroscopy. The new compounds (Va-f) synthesized were evaluated for antimicrobial activity.

Conclusion: All the compounds Va-f screened for antimicrobial activity against selected strains of microorganisms. Compound Vb was found to be potent against Escherichia coli, Vc was found to be more active against Aspergillus niger.

Keywords: 1,2,4-Triazole, Indole, Antibacterial activity, Antifungal activity.

(C) 2019 The Authors. Published by Innovare Academic Sciences Pvt Ltd. This is an open access article under the CC BY license (http://creativecommons. org/licenses/by/4. 0/) DOI: http://dx.doi.org/10.22159/ajpcr.2019.v12i10.35004

\section{INTRODUCTION}

The indole nucleus is an important structure in many natural or synthetic alkaloids. Indole is an aromatic heterocyclic organic compound with formula $\mathrm{C}_{8} \mathrm{H}_{7} \mathrm{~N}$. It has a bicyclic structure consisting sixmembered benzene ring fused with five-membered nitrogen-containing pyrrole ring. The amino acid tryptophan and neurotransmitter serotonin are indole derivatives which confirm the importance of indole in pharmacological and therapeutic activities [1]. Indole compounds include the plant hormone auxin, the anti-inflammatory drug indomethacin, $\beta$-blocker pindolol, and the naturally occurring hallucinogen dimethyltryptamine [2]. The substituted indole has been referred to as privileged structure since they are capable of binding to many receptors with high affinity [3]. The indole ring system is a valuable structural moiety having wide range of pharmacological activities such as analgesic [4], anti-inflammatory [5], antihypertensive [6], antioxidant [7], anticancer [8], antibacterial [9], and antimicrobial [10].

The triazole ring is an essential pharmacophore in modern drug discovery. 1,2,4-triazoles and their derivatives are an important group of heterocyclic compounds identified by a five-membered ring of two carbons and three nitrogen atoms. Triazole derivatives exhibit pharmacological properties such as antioxidant [11], anticancer [12], anti-inflammatory [13], anticonvulsant [14], analgesic [15], antimicrobial [16], and antitubercular [17].

\section{METHODS}

Melting points of the newly prepared compounds were determined using DBK Instruments melting point apparatus and are uncorrected. The infrared (IR) spectra of the newly prepared compounds were recorded on BRUKER attenuated total reflectance IR (ATR-IR) spectrophotometer. The ${ }^{1} \mathrm{H}$ nuclear magnetic resonance (NMR) spectral analysis was done using $\mathrm{CDCl}_{3}$ as solvent on INOVA NMR spectrometer at $400 \mathrm{MHz}$ frequency. Electron impact mass spectra (EI-MS) were recorded on VG Autospec MS. Purity of the compounds and reaction completion was checked using TLC. Ethyl acetate and chloroform in the ratio of $8: 2 \mathrm{v} / \mathrm{v}$ were used as mobile phase for elution and the spots were detected in iodine chamber. Bacterial and fungal strains were obtained from IMTECH, Chandigarh, India. Ampicillin and amphotericin B were purchased from Sigma-Aldrich, Bangalore, India.

\section{Procedure}

Synthesis of ethyl 5-chloro-2-methyl-1H-indole-3-carboxylate (Compound III) In a flat bottom flask $(250 \mathrm{ml})$ fitted with a reflux condenser on a magnetic stirrer, a mixture of chlorophenylhydrazine hydrochloride $(17.9 \mathrm{~g})$, ethyl acetoacetate $(13 \mathrm{ml})$, and glacial acetic acid $(6 \mathrm{ml})$ with a constant stirring and reflux for $2 \mathrm{~h}$. After $2 \mathrm{~h}$, the mixture was cooled and poured in ice water by continuous stirring. Then, the reaction mixture was kept in refrigerator. After forming precipitate filtered and kept for drying. The crude product thus obtained was recrystallized with ethanol [18].

Synthesis of 5-chloro-2-methyl-1H-indole-3-carbohydrazide (Compound IV) Ethanolic solution of compound III $(10.86 \mathrm{~g}, 0.05 \mathrm{~mol})$ was refluxed with hydrazine hydrate $(2.5 \mathrm{~g}, 0.05 \mathrm{~mol})$ for $3 \mathrm{~h}$ at $70^{\circ} \mathrm{C}$. The reaction mixture was allowed to cool and poured over crushed ice. Therefore, solid obtained was filtered and dried. The crude product thus obtained was recrystallized from ethanol [19].

General procedure for synthesis of 5-chloro-2-methyl-3-(5-substitutedphe nyl-4H-1,2,4-triazol-3-yl)-1H-indole (Compound Va-f)

To a solution of compound IV ( $0.1 \mathrm{~mol})$ in acetic acid $(20 \mathrm{ml})$, a pinch of ammonium acetate was added followed by the addition of aromatic aldehydes $(0.1 \mathrm{~mol})$. The mixture was stirred for $24 \mathrm{~h}$ at room temperature. The mother liquor on neutralization with ammonia solution gave a solid, which was filtered and recrystallized from ethanol [20]. The schematic representation of synthesis of target compounds is shown in Fig. 1. 


\section{Antimicrobial screening}

All synthesized compounds were accessed for in vitro antibacterial action by utilizing two Gram-positive bacteria, namely, Bacillus subtilis (MTCC 441) and Staphylococcus aureus (MTCC 3160), two Gramnegative bacteria, namely, Pseudomonas aeruginosa (MTCC 424) and Escherichia coli (MTCC 443), and antifungal activity by utilizing two fungi, namely, Candida albicans (MTCC 227) and Aspergillus niger (MTCC 282) by cup plate method at $100 \mu \mathrm{g} / 0.1 \mathrm{ml}$. Ampicillin and amphotericin B were utilized as standard reference for comparing the antibacterial and antifungal activity, respectively.

\section{Cup plate method}

Determination of antimicrobial activity was done by measuring the zone of inhibition using cup plate method [21]. The test tube containing sterile soft melted agar ( $2 \%$ in distilled water, $6 \mathrm{ml}$ ) was maintained at $50^{\circ} \mathrm{C}$, inoculated with $0.2 \mathrm{ml}$ suspension of test culture, blended well, poured in the pre-sanitized Petri plates containing clean supplement of agar medium and permitted to set for $5 \mathrm{~min}$. Bores measuring approximately $8 \mathrm{~mm}$ in diameter were made on the medium using sterile borer. Then, the standard and test solution in concentration of $100 \mu \mathrm{g} / 0.1 \mathrm{ml}$ were prepared for antibacterial and antifungal test with $\mathrm{N}, \mathrm{N}$-dimethylformamide (DMF). With the help of micropipette, $0.1 \mathrm{ml}$ of standard and test solution were added to the respective bores. At this point, the test and standard are kept in refrigerator for $1 \mathrm{~h}$ for diffusion to take place. Afterward, the plates were incubated in upright position at $37^{\circ} \mathrm{C}$ for $24 \mathrm{~h}$ for microbial growth. DMF was utilized as blank. The diameter of zone of inhibition $(\mathrm{mm})$ around each bore was measured and shown in Table 1

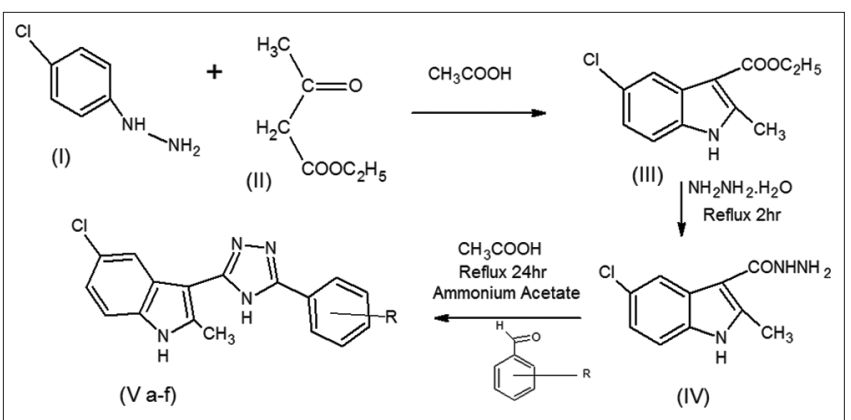

Fig. 1: Schematic representation of synthesized compound Va-f

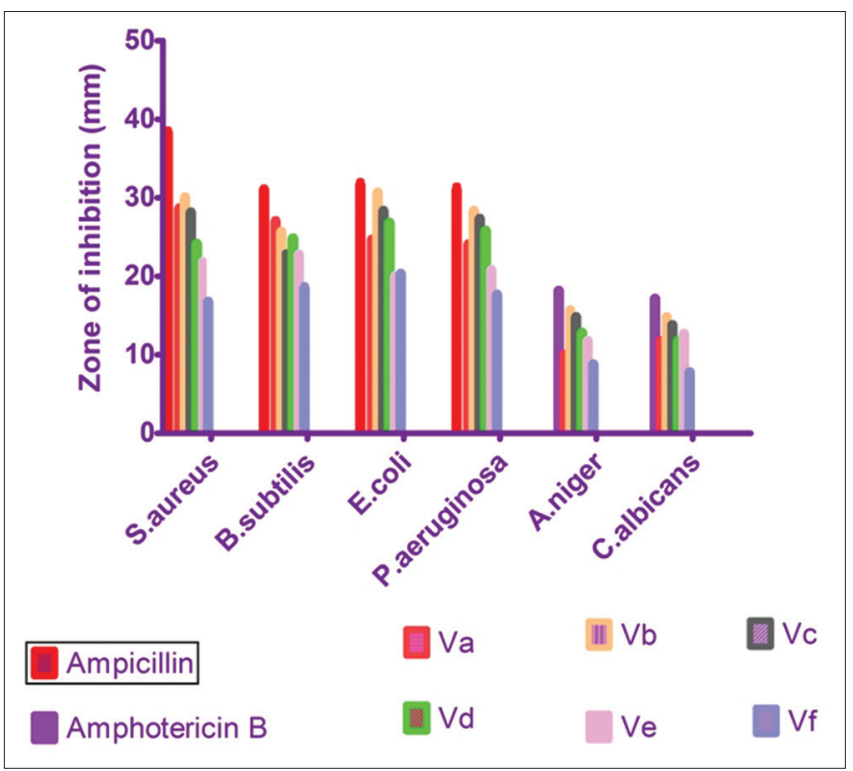

Fig. 2: Graphical representation of antimicrobial activity of Va-f by cup plate method

\section{Minimum inhibitory concentration (MIC) method}

The MICs of newly synthesized compounds (Va-f) were determined by serial dilution method [22]. The minimal concentration of a compound preventing the appearance of turbidity is considered as MIC. All the incorporated compounds were dissolved separately to prepare stock solution containing $1000 \mu \mathrm{g} / \mathrm{ml}$ in DMF. The test compounds (Va-f) (20 mg) were dissolved in $2 \mathrm{ml}$ of the DMF and $1 \mathrm{ml}$ of this solution was aseptically exchanged to the sterile nutrient broth medium and made up to $10 \mathrm{ml}$ with sterile nutrient broth media; thus, $1 \mathrm{ml}$ of the resulted solution gives $1000 \mu \mathrm{g} / \mathrm{ml} .1 \mathrm{ml}$ of the above solution was transferred to $1 \mathrm{ml}$ of DMF to give half the concentration of first. Thus, successive concentrations such as $500,250,125,62.5,31.25,15.62,7.81,3.90$, and $1.95 \mu \mathrm{g} / \mathrm{ml}$ were prepared in similar manner up to eight dilutions. From $8^{\text {th }}$ dilution, $1 \mathrm{ml}$ of the solution is removed and disposed of. The tubes were mixed well after each addition. The experimental MIC values are presented in Table 2.

\section{RESULTS AND DISCUSSION}

5-chloro-2-methyl-1H-indole-3-carbohydrazide (IV) was reacted with different aromatic aldehydes to form 5-chloro-2-methyl-3(5-substituted phenyl-4H-1,2,4-triazol-3-yl)- $1 H$-indole derivatives (Va-f), which is an example for cyclization by ammonium acetate to triazoles. The formation of Va-f, from 5-chloro-2-methyl-1Hindole-3-carbohydrazide (IV), was indicated by its IR, NMR, and MS. Physicochemical data of 5-chloro-2-methyl-3-(5-phenyl-4H-1,2,4triazol-3-yl)-1H-indoles (Va-f) was shown in Table 3

The Fourier transform infrared (FTIR) spectrum of compound (Va) exhibited peak at $3203 \mathrm{~cm}^{-1}$ which was due to $\mathrm{N}-\mathrm{H}$ stretching vibration of indole. The $\mathrm{C}=\mathrm{N}$ stretching vibration of triazole heteroaromatic ring was observed at $1586 \mathrm{~cm}^{-1}$ and $1563 \mathrm{~cm}^{-1}$. The $\mathrm{C}=\mathrm{C}$ aromatic stretching vibration peaks were observed at $1489 \mathrm{~cm}^{-1}$. The aliphatic stretching vibration bands for C-H peak appeared at $2967 \mathrm{~cm}^{-1}$ and $2844 \mathrm{~cm}^{-1}$. Singlets observed at $\delta$ value $11.3 \mathrm{ppm}$ and $11.9 \mathrm{ppm}$ confirm the presence of $\mathrm{NH}$ protons of triazole and indole. A singlet at $\delta$ value $1.5 \mathrm{ppm}$ is due to methyl protons $\left(\mathrm{CH}_{3}\right)$, multiplet at $\delta$ value $6.8-7.6$ confirms the presence of eight aromatic protons. $A M+1$ peak observed at $\mathrm{m} / \mathrm{z}$ value 310 confirms the molecular weight of compound Va. The spectral data of title compounds $\mathrm{Va}, \mathrm{Vb}, \mathrm{Vc}, \mathrm{Vd}, \mathrm{Ve}$, and $\mathrm{Vf}$ were given below.

5-chloro-2-methyl-3-(5-phenyl-4H-1,2,4-triazol-3-yl)-1H-indole (Va) ATR-IR ( $v_{\max } \mathrm{cm}^{-1}$ ): 3203 (NH str. of indole), 3024 (Ar C-H str.), 1586, $1563\left(\mathrm{C}=\mathrm{N}\right.$ ), 2967, 2844 (Aliphatic C-H str.), 1489 (C=C); ${ }^{1} \mathrm{H}$ NMR (400 $\mathrm{MHz}, \mathrm{CDCl}_{3}$ ), $\delta$ ppm: 1.5 (s, 3H, $\mathrm{CH}_{3}$ ), 6.8-7.6 (m, 8H, ArH), $11.3(\mathrm{~s}, 1 \mathrm{H}$, triazole $\mathrm{NH}), 11.9(\mathrm{~s}, 1 \mathrm{H}$, indole $\mathrm{NH})$. MS: $(\mathrm{m} / \mathrm{z}=310)$.

5-chloro-3-[5-(4-chlorophenyl)-4H-1,2,4-triazol-3-yl]-2-methyl$1 \mathrm{H}$-indole (Vb)

ATR-IR $\left(v_{\max } \mathrm{cm}^{-1}\right): 3429$ (NH str. of indole), 1592, 1568 (C=N), 2967, 2921 (Aliphatic C-H str.), 1488 (C=C). ${ }^{1} \mathrm{H}$ NMR (400 MHz, $\left.\mathrm{CDCl}_{3}\right), \delta$ ppm: $2.4\left(\mathrm{~s}, 3 \mathrm{H}, \mathrm{CH}_{3}\right), 7.0-8.3(\mathrm{~m}, 7 \mathrm{H}, \mathrm{ArH}), 11.3(\mathrm{~s}, 1 \mathrm{H}$, triazole $\mathrm{NH})$, $11.9(\mathrm{~s}, 1 \mathrm{H}$, indole $\mathrm{NH})$. MS (m/z= 343).

5-choloro-2-methyl-3-[5-(3-nitrophenyl)-4H-1,2,4-triazol-3yl]$1 \mathrm{H}$-indole (Vc)

ATR-IR ( $\left.v \mathrm{~cm}^{-1}\right): 3384$ (NH str. of indole) 2942 (Aliphatic C-H str), $1468(\mathrm{C}=\mathrm{C}) .{ }^{1} \mathrm{H}$ NMR $\left.400 \mathrm{MHz}, \mathrm{CDCl}_{3}\right), \delta \mathrm{ppm}\left(\mathrm{s}, 3 \mathrm{H}, \mathrm{CH}_{3}\right), 7.1-7.6(\mathrm{~m}, 7 \mathrm{H}$, $\mathrm{ArH}), 11.8(\mathrm{~s}, 1 \mathrm{H}$, triazole $\mathrm{NH}), 11.6(\mathrm{~s}, 1 \mathrm{H}$, indole $\mathrm{NH}) . \mathrm{MS}(\mathrm{m} / \mathrm{z}=354)$.

5-cloro-3-[5-4-methoxy phenyl)-4H-1,2,4-triazol-3yl]-2-methyl1H-indole (Vd)

ATR-IR $\left(v \quad \mathrm{~cm}^{-1}\right): 3231$ (NH str. of indole) 1575, $1552(\mathrm{C}=\mathrm{N}), 2846$ (Aliphatic $\mathrm{C}-\mathrm{H}$ str.) $1470(\mathrm{C}=\mathrm{C}) .{ }^{1} \mathrm{H}$ NMR $400 \mathrm{MHz}, \mathrm{CDCl}_{3}$ ), $\delta$ ppm: 3.3 $\left(\mathrm{s}, 3 \mathrm{H}, \mathrm{CH}_{3}\right), 3.4\left(\mathrm{~s}, 3 \mathrm{H}, \mathrm{OCH}_{3}\right), 7.2-7.8(\mathrm{~m}, 8 \mathrm{H}, \mathrm{ArH}), 11.2(\mathrm{~s}, 1 \mathrm{H}$, triazole $\mathrm{NH}), 11.9(\mathrm{~s}, 1 \mathrm{H}$, indole $\mathrm{NH})$. MS ( $\mathrm{m} / \mathrm{z}=339)$.

5-chloro-2-methyl-3-[3,4,5-trimethoxyphenyl)-4H-1,2,4-triazol-3yl]-2-methyl-1H-indole (Ve)

ATR-IR $\left(v_{\max } \mathrm{cm}^{-1}\right)$ : $3237(\mathrm{NH}$ str. of indole) $1579(\mathrm{C}=\mathrm{N})$ 2922, 2865 (Aliphatic C-H str.) 1488 (C=C); ${ }^{1} \mathrm{H}$ NMR $400 \mathrm{MHz}, \mathrm{CDCl}_{3}$ ), $\delta$ ppm: 2.6 
Table 1: Zone of inhibition of 5-chloro-2-methyl-3-(5-phenyl-4H-1,2,4-Triazol-3-yl)-1H-indoles (Va-f)

\begin{tabular}{|c|c|c|c|c|c|c|c|}
\hline \multirow[t]{3}{*}{ Compound code } & \multirow[t]{3}{*}{$\mathbf{R}$} & \multicolumn{6}{|c|}{ Zone of inhibition ( $\mathrm{mm}$ ) } \\
\hline & & \multicolumn{4}{|c|}{ Bacterial strain } & \multicolumn{2}{|c|}{ Fungal strain } \\
\hline & & S. aureus & B. subtilis & E. coli & P. aeruginosa & A. niger & C. albicans \\
\hline $\mathrm{Va}$ & $-\mathrm{H}$ & 29 & 27 & 25 & 24 & 10 & 12 \\
\hline $\mathrm{Vb}$ & $-\mathrm{Cl}$ & 30 & 26 & 31 & 28 & 16 & 15 \\
\hline $\mathrm{Vc}$ & $-\mathrm{m}-\mathrm{NO}_{2}$ & 28 & 23 & 28 & 27 & 15 & 14 \\
\hline $\mathrm{Vd}$ & $-\mathrm{OCH}_{3}{ }^{2}$ & 24 & 25 & 27 & 26 & 13 & 12 \\
\hline Vf & $-\left(\mathrm{CH}_{3}\right)_{2} \mathrm{NH}^{3}$ & 17 & 19 & 20 & 18 & 9 & 8 \\
\hline Ampicillin & $-\quad 302$ & 37 & 31 & 32 & 30 & - & - \\
\hline Amphotericin B & - & - & - & - & & 18 & 17 \\
\hline
\end{tabular}

S. aureus: Staphylococcus aureus, B. subtilis: Bacillus subtilis, E. coli: Escherichia coli, P. aeruginosa: Pseudomonas aeruginosa, A. niger: Aspergillus niger,

C. albicans: Candida albicans

Table 2: Minimum inhibitory concentration of compounds 5-chloro-2-methyl-3-(5-phenyl-4H-1,2,4-triazol-3-yl)-1H-indoles (Va-f)

\begin{tabular}{|c|c|c|c|c|c|c|c|}
\hline \multirow[t]{3}{*}{ Compound code } & \multirow[t]{3}{*}{$\mathbf{R}$} & \multicolumn{6}{|c|}{ Minimum inhibitory concentration $(\mu \mathrm{g} / \mathrm{ml})$} \\
\hline & & \multicolumn{4}{|c|}{ Bacterial strain } & \multicolumn{2}{|c|}{ Fungal strain } \\
\hline & & S. aureus & B. subtilis & E. coli & P. aeruginosa & A. niger & C. albicans \\
\hline Va & $-\mathrm{H}$ & 3.91 & 3.91 & 62.5 & 62.5 & 250 & 250 \\
\hline $\mathrm{Vb}$ & $-\mathrm{Cl}$ & 3.91 & 31.25 & 15.62 & 31.25 & 125 & 125 \\
\hline $\mathrm{Vc}$ & $-\mathrm{m}-\mathrm{NO}_{2}$ & 3.91 & 31.25 & 62.5 & 31.25 & 250 & 250 \\
\hline $\mathrm{Vd}$ & $-\mathrm{OCH}_{3}{ }^{2}$ & 125 & 62.5 & 62.5 & 31.25 & 250 & 250 \\
\hline Ve & $-3,4,5-\mathrm{OCH}_{3}$ & 62.5 & 125 & 250 & 125 & 250 & 250 \\
\hline $\mathrm{Vf}$ & $-\left(\mathrm{CH}_{3}\right)_{2} \mathrm{NH}^{3}$ & 250 & 250 & 250 & 250 & 500 & 500 \\
\hline Ampicillin & $-\quad 302$ & 1.95 & 1.95 & 7.81 & 15.62 & - & - \\
\hline Amphotericin B & - & - & - & - & - & 3.91 & 7.81 \\
\hline
\end{tabular}

S. aureus: Staphylococcus aureus, B. subtilis: Bacillus subtilis, E. coli: Escherichia coli, P. aeruginosa: Pseudomonas aeruginosa, A. niger: Aspergillus niger,

C. albicans: Candida albicans

Table 3: Physicochemical data of 5-chloro-2-methyl-3-(5-phenyl-4H-1,2,4-triazol-3-yl)-1H-indoles (Va-f)

\begin{tabular}{lllllll}
\hline S. No. & Compound code & R & M.F & M.P & \% yield \\
\hline 1 & $\mathrm{Va}$ & $-\mathrm{H}$ & $\mathrm{C}_{18} \mathrm{H}_{17} \mathrm{ClN}_{4}$ & $140^{\circ} \mathrm{C}$ & 75 & Rf \\
2 & $\mathrm{Vb}$ & $-4-\mathrm{Cl}$ & $\mathrm{C}_{17} \mathrm{H}_{12} \mathrm{ClN}_{4}$ & $180^{\circ} \mathrm{C}$ & 90 & 0.82 \\
3 & $\mathrm{Vc}$ & $-\mathrm{MNO}_{2}$ & $\mathrm{C}_{17} \mathrm{H}_{12} \mathrm{ClN}_{5} \mathrm{O}_{2}$ & $195^{\circ} \mathrm{C}$ & 78 & 0.90 \\
4 & $\mathrm{Vd}$ & $-\mathrm{CCH}^{3}$ & $\mathrm{C}_{18} \mathrm{H}_{15} \mathrm{ClN}_{2} \mathrm{O}$ & $140^{\circ} \mathrm{C}$ & 85 & 0.64 \\
5 & $\mathrm{Ve}$ & $-3,4,5-\mathrm{OCH}^{3}$ & $\mathrm{C}_{20} \mathrm{H}_{19} \mathrm{ClN}_{4} \mathrm{O}_{3}$ & $130^{\circ} \mathrm{C}$ & 80 & 0.75 \\
6 & $\mathrm{Vf}$ & $-\left(\mathrm{CH}_{3}\right)_{2} \mathrm{NH}$ & $\mathrm{C}_{19} \mathrm{H}_{18} \mathrm{ClN}_{5}$ & $190^{\circ} \mathrm{C}$ & 88 & 0.84 \\
\hline
\end{tabular}

M.F: Molecular formula, M.P: Melting point, Rf: Retardation factor

(s, $\left.3 \mathrm{H}, \mathrm{CH}_{3}\right), 3.2\left(\mathrm{~s}, 3 \mathrm{H}, \mathrm{OCH}_{3}\right), 3.9\left(\mathrm{~s}, 6 \mathrm{H}, \mathrm{OCH}_{3}\right), 7.2-7.8(\mathrm{~m}, 5 \mathrm{H} . \mathrm{ArH})$, $11.4(\mathrm{~s}, 1 \mathrm{H}$, triazole $\mathrm{NH}), 11.9$ (s,1H, indole $\mathrm{NH})$. MS (m/z=399)

4-[5-(-cholro-2-methyl-1H-indole-3-yl)-4H-1,2,4-triazol-3-yl]-N,Ndimethyl aniline (Vf)

ATR-IR $\left(v_{\max } \mathrm{cm}^{-1}\right):$ 3203(NH str. of indole), $1552(\mathrm{C}=\mathrm{N}) 2949,2912$ (Aliphatic C-H str) $1487(\mathrm{C}=\mathrm{C}) ;{ }^{1} \mathrm{H}$ NMR $\left.400 \mathrm{MHz}, \mathrm{CDCl}_{3}\right)$, 8 ppm: 2.8 $\left(\mathrm{s}, 2 \mathrm{H}, \mathrm{CH}_{3}\right), 3.7\left(\mathrm{~s}, 6 \mathrm{H}, \mathrm{OCH}_{3}\right), 6.8-8(\mathrm{~m}, 8 \mathrm{H}, \mathrm{ArH}), 11.2(\mathrm{~s}, 1 \mathrm{H}$, triazole $\mathrm{NH}), 11.6(\mathrm{~s}, 1 \mathrm{H}$, indole $\mathrm{NH})$. MS (m/z=352).

\section{Antibacterial studies}

The antibacterial potency of the newly synthesized compounds Va-f was tested against human pathogens S. aureus, B. subtilis, E. coli, and $P$. aeruginosa. The compounds were tested at $100 \mu \mathrm{g} / 0.1 \mathrm{ml}$ concentration against all the selected bacteria and the results are shown in Table 1. The results of antibacterial studies showed all the test compounds possess moderate to good activity against S. aureus, B. subtilis, E. coli, and P. aeruginosa. The compounds $\mathrm{Vb}$ and $\mathrm{Vc}$ substituted with electron-withdrawing groups such as chloro and nitro exhibited enhanced activity against $E$. coli and $P$. aeruginosa. The zone of inhibition data from cup plate method revealed that introduction of electron-donating groups such as methoxy, 3,4,5-trimethoxy, and $\mathrm{N}, \mathrm{N}$-dimethylamino groups on phenyl ring was detrimental to the antibacterial activity. The compound Va with no substitution on phenyl ring was more active than compounds with electron-donating group substitutions.

\section{Antifungal studies}

All the targeted compounds showed antifungal activity against the tested fungal strains A. niger and C. albicans. Compounds Vb and Vc were found to be effective against both fungal species as reveled from data (Tables 1 and 2). Compound $\mathrm{Vb}$ and $\mathrm{Vc}$ showed good activity against $A$. niger and C. albicans. Compound $\mathrm{Vb}$ was most potent among all synthesized derivatives, whereas compound $\mathrm{Va}, \mathrm{Vd}$, Ve, and Vf showed weak to moderate activity against both fungal species. Graphical representation of antimicrobial activity of compounds (Va-f) by cup plate method was presented in Fig. 2.

\section{CONCLUSION}

Antibiotics are the most common weapons to fight against bacterial infections, but the resistance is gradually developed due to the overuse and misuse of antibiotics. Hence, there is constant need to develop novel antibiotics. Hybrid molecules have the capacity to overcome drug resistance. 1,2,4-triazole and indole derivatives possess promising antimicrobial activity, so hybridization of 1,2,4-triazole and indole 
is rationale strategy to develop new antimicrobial candidates. In the current research work, compounds (Va-f) were successfully synthesized and confirmed by FTIR, ${ }^{1} \mathrm{HNMR}$, and mass spectroscopy and screened for antimicrobial activity. By looking at the results of all compounds, we came to conclusion that the compounds with electron-withdrawing groups such as $\mathrm{Vb}$ and $\mathrm{Vc}$ showed enhanced antibacterial activity and antifungal activity.

\section{ACKNOWLEDGMENTS}

The authors would like to express gratitude to Dr. A. Venkateshwar Reddy, Principal, Anwarul Uloom College of Pharmacy, Hyderabad, for providing laboratory facilities to carry out this work. We also thank the Indian Institute of Chemical Technology, Hyderabad, for providing NMR and MS.

\section{AUTHOR'S CONTRIBUTIONS}

Saba Shireen performed the synthesis of compounds and wrote the manuscript. Dr. P. Bharath Rathna Kumar performed FTIR spectroscopy and done spectral interpretation. Saba Shireen and Dr. P. Bharath Rathna Kumar performed antimicrobial activity.

\section{CONFLICTS OF INTEREST}

The authors declare that they have no conflicts of interest.

\section{REFERENCES}

1. Shahid S, Naziabegum S, Zamir MD, Salunke SD and Baseer MA. Synthesis of new 2-substituted phenyl-1H-indole reaction. Chem Sci Trans 2013;2:584-8.

2. Nagaraju G, Sai KB, Saimeghana M, Chandana K, Ramarao N. Synthesis, Characteriztion and biological activity of indole-2-carboxylic acid derivatives. Int J Pharm Chem 2015;5:201-6.

3. Imtiyaz AK, Firdous GK, Minhaaj R. Synthesis, characterization and antimicrobial evaluation of some new N-(2,4-di chloloro benzyl)- indolylchalcones. J Chem Pharm Res 2013;5:631-6.

4. Sharma V, Kumar P, Pathak D. Biological importance of the indole nucleus in recent years: A comprehensive review. J Heterocycl Chem 2010;47:491-502.

5. Narayana B, Ashalatha BV, Vijaya Raj KK, Fernandes J, Sarojini BK. Synthesis of some new biologically active 1,3,4-oxadiazolyl nitroindoles and a modified fischer indole synthesis of ethyl nitro indole-2carboxylates. Bioorg Med Chem 2005;13:4638-44.

6. Saravanan B, Akhilesh U, Bhaskar A, Manivannan V. Synthesis and molecular docking studies of diethyl 2-\{[3-(2,4,6-trimetjhylbenzyl1-phenyl sulfonyl-1H-indol-2-yl]methyidene $\}$ propanedioate against hypertensive protein as a potential target. Asian J Pharm Clin Res 2013;6:172-4

7. Saravanan B, Akhilesh U, Bhaskar A, Manivannan V. Synthesis, characterization and biological evaluation of indole derivatives bearing Benzimidazole benzothiazole moiety. Int J Pharm Pharm Sci 2017;9:128-38.

8. Mashayekhi V, Haj Mohammad Ebrahim Tehrani K, Azerang P, Sardari S, Kobarfard F. Synthesis, antimycobacterial and anticancer activity of novel indole-based thiosemicarbazones. Arch Pharm Res 2013. https://doi.org/10.1007/s12272-013-0242-z.

9. Doddappa PA, Biradar JS. Synthesis characterization and antimicrobial activities of 2-(5-subsituted 3-phenyl-1H-indole-2-yl)-5-subsituted$7 \mathrm{H}-[1,3,4]$ oxadiazolo/thidiazolo[3,2-a][1,3,5] triazine-7-thiaones. J Chem Pharm Res 2013;5:75-85.

10. Kumar A, Sing CP. Synthesis, characterization and biological activity of some new sulpha/substituted phenylazo indoles. Int J Sci Res 2015;4:934-8.

11. Swami PV, Kumar VK, Reddy RV, Anindita C. Microwave assisted synthesis, characterization and biological evaluation of phenyl acrylamide derivatives of triazoles derived from oxazolones. Asian J Pharm Clin Res 2018;11:285-90.

12. El-Sayed WA, Eman MF, Eman MH. Anticancer and antimicrobial activities of some synthesized pyrazle and triazole derivatives. J Pharm Chem 2012;4:23-32

13. Pradeep KG, Bhandari A, Rana AC. Synthesis of some 3-Substituted4H-1, 2, 4-triazole derivatives with potent anti-inflammatory activity. Asian J Pharm Clin Res 2010;3:244-6.

14. Sudhir NS, Suhas AP. Synthesis of 3-substituted-4-amino-5-mercapto4(H)-1, 2, 4- triazole and screening for anti-convulsant activity. Int J Res Pharm Bio Sci 2011;2:520-4

15. Khanage S, Popat BM, Ramdas BP, Raju S. Study of analgesic activity of novel 1,2,4-triazole derivatives bearing pyrazole and tetrazole moiety. J Pharm Res 2011;4:609-11.

16. Kumar PD, Singh V, Deepak PD, Kumar MR. Synthesis, characterization and antimicrobial evaluation of some 1, 2, 4-triazole derivatives. Int J Pharm Sci Res 2014;6:213-6.

17. Dasan N, Babu G, George S. Molecular docking studies and synthesis of 3,4-disubstituted triazoles as mycobacterium tuberculosis enoyl-ACP reductase and CYP-51 inhibitors. Int J Pharm Pharm Sci 2019;11:85-91.

18. Kumari M, Narang R, Naik SK, Singh SK, Gupta V, Balasubramanian N. Synthesis, molecular modeling and quantitative structure activity relationship studies of undec-10-enehydrazide derivatives as antimicrobial agents. Asian J Pharm Clin Res 2017;10:94-105.

19. Kumar PB, Subramaniyan S, Yamini K, Suthakaran R. Synthesis of some novel-1H-pyrazole derivatives and their antibacterial activity studies. Rasayan J Chem 2011;4:400-4

20. Singh DV, Ram MA, Mani MR. Synthesis and characterization of some antifungal pyrimidinone derivatives. Indian J Heterocycl Chem 2004; $14: 43-6$.

21. Black JG. Microbiology Principles and Exploration. $4^{\text {th }}$ ed. New Delhi: Prentice-Hall; 1991. p. 163.

22. Goto S, Jo K, Kawakita T, Mitsuhashi S, Nishino T, Ohsawa N, et al. Determination method of minimum inhibitory concentrations. Chemother 1981;29:76-9. 